\title{
Hormonal and follicular factors affecting maturation of sheep oocytes in vitro and their subsequent developmental capacity
}

\author{
R. M. Moor and A. O. Trounson* \\ Agricultural Research Council Unit of Reproductive Physiology \& Biochemistry, \\ 307 Huntingdon Road, Cambridge CB3 OJQ, U.K.
}

Summary. Oocytes removed from, or retained within, non-atretic and atretic follicles of different sizes were cultured for $24 \mathrm{~h}$ in the presence of a variety of hormones in an attempt to identify the factors affecting oocyte maturation in vitro. Resumption of meiosis was assessed morphologically; the developmental capacity of oocytes after culture was determined by transfer to the oviducts of inseminated ewes.

About $70 \%$ of oocytes cultured after removal from follicles of different sizes resumed meiosis in vitro, but they did not undergo normal development after transplantation.

Oocytes cultured within the follicle in hormone-free medium remained at the germinal vesicle stage. In the presence of FSH and LH some oocytes reached the second meiotic metaphase: $19 \%$ in small (2-3 mm diam.) and $73 \%$ in larger (3-5 mm diam.) non-atretic follicles, and $54 \%$ in small and $45 \%$ in larger atretic follicles.

Less than $5 \%$ of oocytes cultured in follicles developed into normal blastocysts after transplantation when either no hormone or only FSH and LH were added to the culture medium. The addition of oestradiol-17 $\beta$ to medium containing FSH $(2 \mu \mathrm{g} / \mathrm{ml})$ and $\mathrm{LH}(1 \mu \mathrm{g} / \mathrm{ml})$ resulted in the development to blastocysts of $26 \%$ of oocytes from small non-atretic follicles, $46 \%$ from large non-atretic follicles and $50 \%$ from atretic follicles. Blastocyst formation was greatly depressed and fragmentation rate signifcantly increased with concentrations of $10 \mu \mathrm{g} \mathrm{FSH} / \mathrm{ml}$ and $2 \mu \mathrm{g} \mathrm{LH} / \mathrm{ml}$.

Developmental capacity after culture was further demonstrated by the birth of lambs from $63 \%$ of blastocysts derived from oocytes matured in vitro; $52 \%$ of control blastocysts developed to lambs after transfer.

\section{Introduction}

Although mammalian oocytes removed from the follicle readily undergo meiotic maturation in vitro (Pincus \& Enzmann, 1935), their subsequent development seldom progresses beyond the first few cleavage divisions (Chang, 1955; Cross \& Brinster, 1970; Mukherjee, 1972). The developmental incompetence displayed by oocytes matured in vitro probably results from abnormalities in the meiotic process (McGaughey \& Polge, 1971) and in the maturation of the cytoplasm (Thibault, Gérard \& Menezo, 1975).

The purpose of the present study was to identify in vitro the hormonal and cellular factors affecting maturation and subsequent embryonic development of sheep oocytes. Factors affecting maturation of oocytes cultured outside the follicle are described in the first two experiments. The remaining four experiments are concerned with the effect of gonadotrophins, steroids, follicle size and degree of atresia on the maturation and development of oocytes cultured within intact follicles.

* Present address: University of Monash, Department of Obstetrics \& Gynaecology, Queen Victoria Memorial Hospital, Melbourne, Victoria 3000, Australia. 


\section{Materials and Methods}

\section{Tissue preparation and culture methods}

Ovaries were obtained during the breeding season from 115 non-pregnant sheep of various breeds slaughtered at a local abattoir and from a further 75 Welsh Mountain sheep at laparotomy, The dissection and measurement of the follicles was carried out at $20^{\circ} \mathrm{C}$ in medium consisting of Dulbecco's phosphate-buffered saline (PBS) supplemented with $4 \mathrm{mg}$ bovine serum albumin (BSA, Fraction V: Sigma, London) $/ \mathrm{ml}$ and $50 \mu \mathrm{g}$ kanamycin sulphate (Sigma, London) $/ \mathrm{ml}$. After dissection, the follicles were classified under a stereoscopic microscope into three groups on the basis of their opacity, vascularization and the integrity and uniformity of the membrana granulosa (R. M. Moor, M. F. Hay, D. Cran \& H. M. Dott, unpublished). Follicles with a bright translucent appearance, good vascularization and a regular granulosa were classified as non-atretic. Grossly atretic follicles were opaque, poorly vascularized, had an irregular or detached membrana granulosa and often had large atretic bodies visible in the antral cavity. Follicles that could not with confidence be placed in either of the above categories (usually those in the early stages of atresia) were not used in this study. The above macroscopic criteria have been found to correlate closely with subsequent histological assessment of atresia; approximately $90-95 \%$ of follicles classified macroscopically as atretic were subsequently shown to be undergoing secondary or tertiary atresia (Hay, Cran \& Moor, 1976).

In Exps 1 and 2 the entire complex of cumulus, corona and oocyte was dissected from the follicle (extrafollicular oocytes), washed free of follicular fluid and cultured in stoppered test-tubes. Two media were used for the culture of the extrafollicular oocytes. Medium 199A contained $85 \%$ M199, $15 \%$ calf serum, $56 \mathrm{ng}$ insulin $/ \mathrm{ml}$ and $25 \mu \mathrm{g}$ kanamycin sulphate $/ \mathrm{ml}$ (see Moor, Hay, McIntosh \& Caldwell, 1973). The Medium 199A used in Exps 1 and 2 was supplemented with ovine FSH $(2 \mu \mathrm{g}$ NIH-FSH-S8 $/ \mathrm{ml})$, ovine LH (1 $\mu \mathrm{g}$ NIH-LH-S18/ml) and oestradiol-17 $(1 \mu \mathrm{g} / \mathrm{ml})$. The other medium (Medium PBS + SS) contained no hormonal additives and consisted of $80 \%$ modified Dulbecco's PBS and $20 \%$ heat-inactivated sheep serum (Trounson, Willadsen \& Rowson, 1976). Oocytes were cultured at $37^{\circ} \mathrm{C}$ for $24 \mathrm{~h}$ in a gas phase of $5 \% \mathrm{CO}_{2}, 5 \% \mathrm{O}_{2}$ and $90 \% \mathrm{~N}_{2}$.

In Exps 3, 4 and 5, oocytes were cultured under various hormonal conditions in intact follicles (intrafollicular oocytes). The follicles were placed on stainless-steel grids in Medium 199A; gonadotrophins and steroids were added in different combinations to the culture medium immediately before explantation (see Tables 3-5 for details). The follicles were maintained at $37^{\circ} \mathrm{C}$ for $24 \mathrm{~h}$ in a humidified atmosphere of $5 \% \mathrm{CO}_{2}$ in air and at a pressure of $1.5 \times 10^{5} \mathrm{~Pa}$.

\section{Evaluation of cultured oocytes}

After $24 \mathrm{~h}$ in vitro, oocytes were removed from the culture tubes or dissected from the follicles and placed in dissection medium. Oocytes destined for nuclear examination were mechanically denuded of surrounding cells, mounted under coverslips, fixed in acetic acid: ethanol $(1: 3 \mathrm{v} / \mathrm{v})$ and stained with lacmoid. The stage of meiosis was identified according to the criteria of Austin (1961).

After $24 \mathrm{~h}$ culture in vitro, fertilization and developmental capacity of oocytes was tested in vivo by transplantation into the fimbrial end of the oviducts of ewes in oestrus. Freshly ejaculated ram semen $(0.01-0.02 \mathrm{ml})$ was placed in both uterine horns of each recipient immediately before transfer of the oocytes. Eggs were removed from the reproductive tract of the host animals 7 days after transfer.

One or two normal blastocysts, corresponding to the number of ovulations in each recipient, were always deducted from the total number of normal embryos obtained to account for those naturally ovulated. However, few if any ovulated oocytes enter the oviduct when the fimbria is disturbed just before ovulation as in the case of the present experiments (R. M. Moor \& A. O. Trounson, unpublished observations). Subsequent transfers were only made from the blastocysts obtained from the uterine horn contralateral to that of the ovary with the CL. All egg stages other than blastocysts were fixed, stained and classified as follows. Single-cell eggs had dispersed or pyknotic chromatin; fragmented eggs contained 2- to 50-cellular fragments which varied in size and were usually anucleate or contained large irregular nuclei with no visible nucleoli; retarded eggs contained 2- to 50-cells with many normal 
nuclei but few if any mitotic figures. Embryos with no apparent defects and in the late morula ( $>50$ normal nuclei) or blastocyst stage ( $>100$ nuclei) were classified as normal. The viability of the blastocysts was assessed by examining their capacity to develop to term in suitable host sheep (Exp. 6).

\section{Results}

Experiment 1: meiotic change in oocytes cultured outside the follicle

The effect of the two culture media on the resumption of meiosis was tested in 94 oocytes removed from follicles of sheep slaughtered between Days 4 and 14 of the cycle. There was no significant difference between the two media in the total number of oocytes reaching the second meiotic division during culture (Table 1). However, the proportion of oocytes that reached metaphase I or anaphase I but failed to progress further during culture was significantly higher in Medium PBS + SS than in Medium 199A ( $44 \%$ versus $\left.10 \% ; \chi_{1}^{2}=12.6 ; P<0 \cdot 01\right)$.

Table 1. Activation of the nucleus in sheep oocytes removed from the follicle and cultured for $24 \mathrm{~h}$

\begin{tabular}{lcccccc}
\hline & & \multicolumn{5}{c}{ State of nucleus } \\
\cline { 5 - 7 } \multicolumn{1}{c}{$\begin{array}{c}\text { No. of } \\
\text { Culture } \\
\text { medium }\end{array}$} & $\begin{array}{c}\text { oocytes } \\
\text { cultured }\end{array}$ & Degenerate & $\begin{array}{c}\text { Germinal } \\
\text { vesicle }\end{array}$ & $\begin{array}{c}\text { Metaphase } \\
\text { I }\end{array}$ & $\begin{array}{c}\text { Anaphase } \\
\text { I }\end{array}$ & $\begin{array}{c}\text { Metaphase } \\
\text { II }\end{array}$ \\
\hline PBS+ SS & 36 & 2 & 4 & 10 & 6 & 14 \\
Medium 199A & 58 & 11 & 11 & 6 & 0 & 30 \\
Total & 94 & 13 & 15 & 16 & 6 & 44 \\
\hline
\end{tabular}

The follicle cells surrounding the oocytes cultured in gonadotrophin-supplemented Medium 199A became dispersed in culture in a manner similar to that seen during oocyte maturation in vivo. In the absence of gonadotrophin (Medium PBS + SS) dispersal of cumulus cells did not occur.

\section{Experiment 2: developmental capacity of oocytes cultured outside the follicle}

The 78 extrafollicular oocytes used in this experiment were obtained from the same animals and were cultured in a manner similar to that described in Exp. 1. After $24 \mathrm{~h}$ in vitro the oocytes were transferred to the oviducts of 10 recipient ewes. Only one of the 61 eggs recovered from the recipient ewes had developed into a normal blastocyst; the remainder were single-celled, fragmenting or severely retarded cleaved eggs (Table 2). These experiments demonstrate that oocytes cultured outside the follicle do not undergo complete maturation in vitro despite the apparently normal developmental sequence in the nucleus and surrounding cumulus cells.

Table 2. Developmental capacity of sheep oocytes cultured for $24 \mathrm{~h}$ outside the follicle and then transferred to the oviducts of inseminated recipient ewes for 7 days

\begin{tabular}{|c|c|c|c|c|c|c|c|}
\hline \multirow{3}{*}{$\begin{array}{l}\text { Culture } \\
\text { medium }\end{array}$} & & & \multicolumn{5}{|c|}{ Embryonic development } \\
\hline & \multicolumn{2}{|c|}{ No. of oocytes } & \multirow{2}{*}{$\begin{array}{c}\text { Single- } \\
\text { cell } \\
\text { eggs }\end{array}$} & \multirow{2}{*}{$\begin{array}{c}\text { Fragmented } \\
\text { eggs }\end{array}$} & \multirow{2}{*}{$\begin{array}{c}\text { Retarded } \\
\text { eggs } \\
(2-50 \text { cells })\end{array}$} & \multirow{2}{*}{$\begin{array}{c}\text { Morulae } \\
(50-100 \\
\text { cells })\end{array}$} & \multirow{2}{*}{$\begin{array}{l}\text { Blastocysts } \\
(>100 \text { cells })\end{array}$} \\
\hline & Transferred & Recovered & & & & & \\
\hline $\begin{array}{l}\text { PBS + SS } \\
\text { Medium }\end{array}$ & 46 & 37 & 10 & 13 & 9 & 4 & 1 \\
\hline $199 \mathrm{~A}$ & 32 & 24 & 11 & 7 & 6 & $\mathbf{0}$ & 0 \\
\hline Total & 78 & 61 & 21 & 20 & 15 & 4 & 1 \\
\hline
\end{tabular}




\section{Experiment 3: meiotic changes in oocytes cultured within the follicle}

It has been reported by Thibault \& Gérard (1973) that rabbit oocytes retained within intact preovulatory follicles undergo normal maturation in vitro. This approach was therefore utilized in our studies to identify the factors necessary for the maturation of sheep oocytes in culture. Intact follicles were divided into groups on the basis of diameter and normality (see Table 3 ). Three groups of follicles were cultured without hormonal supplementation in Medium 199A (Control groups). The Medium 199A used for the remaining four groups was supplemented with $2 \mu \mathrm{g} \mathrm{FSH} \mathrm{(NIH-S8)/ml} \mathrm{and} 1 \mu \mathrm{g}$ LH (NIH-S18)/ml. At the end of the culture period the oocytes were fixed and the degree of nuclear activation assessed.

In the absence of gonadotrophin nuclear activation did not occur, and oocytes from all classes of follicles remained in the dictyate stage throughout the 72-h culture period (Table 3 ). The addition of gonadotrophin to the culture medium initiated meiotic change, but the proportion of oocytes reaching the second metaphase division in vitro was influenced both by follicular size and whether or not atresia had occurred.

Table 3. The effect of gonadotrophins, follicle size and atresia on the activation of the nucleus of sheep oocytes cultured for $24 \mathrm{~h}$ within the follicle

\begin{tabular}{|c|c|c|c|c|c|c|c|c|c|}
\hline \multirow{2}{*}{$\begin{array}{l}\text { Gonadotrophins } \\
\text { added to } \\
\text { culture } \\
\text { medium* }\end{array}$} & \multirow[b]{2}{*}{$\begin{array}{l}\text { Follicle } \\
\text { diam. } \\
\text { (mm) }\end{array}$} & \multirow[b]{2}{*}{$\begin{array}{c}\text { State } \\
\text { of } \\
\text { follicle }\end{array}$} & \multirow[b]{2}{*}{$\begin{array}{c}\text { Culture } \\
\text { period } \\
\text { (h) }\end{array}$} & \multirow[b]{2}{*}{$\begin{array}{l}\text { No. of } \\
\text { follicles } \\
\text { cultured }\end{array}$} & \multicolumn{5}{|c|}{ State of nucleus } \\
\hline & & & & & $\begin{array}{c}\text { De- } \\
\text { generate }\end{array}$ & $\begin{array}{l}\text { Ger- } \\
\text { minal- } \\
\text { vesicle }\end{array}$ & $\begin{array}{l}\text { Meta- } \\
\text { phase- } \\
\text { l }\end{array}$ & $\begin{array}{l}\text { Ana- } \\
\text { phase- } \\
\text { I }\end{array}$ & $\begin{array}{l}\text { Meta- } \\
\text { phase- } \\
\text { II }\end{array}$ \\
\hline 一 & $2-3$ & Non-atretic & 24 & 6 & 0 & 5 & 1 & $\mathbf{0}$ & 0 \\
\hline - & $3-5$ & Non-atretic & 24 & 14 & 0 & 12 & 2 & 0 & 0 \\
\hline - & $3-5$ & Non-atretic & 72 & 9 & 1 & 7 & 1 & 0 & 0 \\
\hline $\mathrm{FSH}+\mathbf{L H}$ & $2-3$ & Non-atretic & 24 & 27 & 2 & 16 & 4 & 0 & 5 \\
\hline $\mathrm{FSH}+\mathrm{LH}$ & $3-5$ & Non-atretic & 24 & 33 & 3 & 2 & 4 & 9 & 15 \\
\hline $\mathbf{F S H}+\mathbf{L H}$ & $2-3$ & Atretic & 24 & 22 & 3 & 5 & 4 & 0 & 10 \\
\hline $\mathbf{F S H}+\mathrm{LH}$ & $3-5$ & Atretic & 24 & 12 & 0 & 2 & 4 & 1 & 5 \\
\hline
\end{tabular}

* Medium 199A supplemented with $2 \mu \mathrm{g}$ NIH-FSH-S8/ml and $1 \mu \mathrm{g}$ NIH-LH-S18/ml.

Two important points emerge from the results presented in Table 3 . In non-atretic follicles significantly more oocytes developed to the second meiotic metaphase in follicles measuring 3-5 $\mathrm{mm}$ in diameter (large follicles) than in smaller follicles of $2-3 \mathrm{~mm}$ diameter $\left(45 \%\right.$ versus $19 \% ; \chi_{1}^{2}=4 \cdot 8$; $P<0.05$ ). By contrast, in atretic follicles the percentage of oocytes reaching metaphase II was high, irrespective of follicular size (large follicles, $41 \%$; smaller follicles, $45 \%$ ). The proportion of oocytes undergoing complete nuclear activation in large and small atretic follicles was therefore similar to that occurring in large non-atretic follicles and was significantly higher than that in small non-atretic follicles $(P<0.05)$.

\section{Experiment 4: developmental capacity of oocytes cultured in non-atretic follicles}

The purpose of this experiment was to examine the effect of gonadotrophins and oestrogen on the maturation and subsequent embryonic development of oocytes cultured for $24 \mathrm{~h}$ within nonatretic follicles of different sizes. A total of 391 follicles, $2-5 \mathrm{~mm}$ in diameter, was obtained from 63 sheep injected $24 \mathrm{~h}$ previously with 1250 i.u. PMSG (Folligon: Intervet) and cultured in Medium 199A supplemented with different combinations of FSH, LH and oestradiol-17ß (see Table 4). After culture, approximately 5 oocytes surrounded by corona and cumulus were transferred to each of the oviducts of 38 inseminated oestrous ewes and examined 7 days later.

Culture without hormones. In the absence of gonadotrophins and oestrogen only one oocyte out of 23 developed into a blastocyst (Table 4), a result similar to that obtained when extrafollicular oocytes were transferred to recipient ewes (Table 2). 
Table 4. Effect of hormones and follicle size on the developmental capacity of oocytes cultured for $24 \mathrm{~h}$ within the follicle and then transferred to the oviducts of inseminated ewes for 7 days

\begin{tabular}{|c|c|c|c|c|c|c|c|c|c|c|}
\hline \multirow{3}{*}{\multicolumn{3}{|c|}{$\begin{array}{l}\text { Hormones in culture medium } \\
\qquad(\mu \mathrm{g} / \mathrm{ml})\end{array}$}} & \multirow{4}{*}{$\begin{array}{c}\text { Follicle } \\
\text { diam. } \\
(\mathrm{mm})\end{array}$} & \multirow{3}{*}{\multicolumn{2}{|c|}{ No. of oocytes }} & \multicolumn{5}{|c|}{ Embryonic development } \\
\hline & & & & & & \multirow{3}{*}{$\begin{array}{c}\text { Single- } \\
\text { celled } \\
\text { eggs }\end{array}$} & \multirow{3}{*}{$\begin{array}{c}\text { Frag- } \\
\text { mented } \\
\text { eggs }\end{array}$} & \multirow{3}{*}{$\begin{array}{c}\text { Retarded } \\
(2-50 \\
\text { cells })^{*}\end{array}$} & \multirow{3}{*}{$\begin{array}{c}\text { Morulae } \\
(50-100 \\
\text { cells })^{*}\end{array}$} & \multirow{3}{*}{$\begin{array}{l}\text { Blasto- } \\
\text { cysts } \\
(>100 \\
\text { cells })\end{array}$} \\
\hline & & & & & & & & & & \\
\hline FSH & LH & Oestradiol-17 $\beta$ & & ferred & covered & & & & & \\
\hline 0 & 0 & 0 & $3-5$ & 31 & 23 & $13^{b}$ & $3^{\mathrm{a}}$ & 6 & 0 & $1^{2}$ \\
\hline 2 & 1 & 0 & $3-5$ & 110 & 87 & $45^{b}$ & $23^{b}$ & 13 & 2 & $4^{b}$ \\
\hline 10 & 2 & 0 & $3-5$ & 61 & 42 & $12^{a}$ & $14^{\mathrm{b}}$ & 9 & 2 & $5^{\mathrm{ab}}$ \\
\hline 2 & 1 & 1 & $2-3$ & 35 & 31 & $12^{\mathrm{ab}}$ & $6^{\mathrm{a}}$ & 5 & 3 & $5^{b}$ \\
\hline 2 & 1 & 1 & $3-5$ & 114 & 96 & $25^{\mathrm{a}}$ & $12^{\mathrm{a}}$ & 15 & 7 & $37^{c}$ \\
\hline 10 & 2 & 1 & $3-5$ & 40 & 32 & $12^{\mathrm{ab}}$ & $11^{\mathrm{b}}$ & 4 & 1 & $4^{a b}$ \\
\hline
\end{tabular}

Different superscripts within columns denote differences at the $5 \%$ level of significance.

* No significant differences between any groups.

Culture with gonadotrophins. Only 5\% of oocytes cultured in large follicles (3-5 $\mathrm{mm}$ diam.) exposed to $2 \mu \mathrm{g} \mathrm{FSH} / \mathrm{ml}$ and $1 \mu \mathrm{g} \mathrm{LH} / \mathrm{ml}$ developed into normal blastocysts. Increasing the gonadotrophin concentration to $10 \mu \mathrm{g} \mathrm{FSH} / \mathrm{ml}$ and $2 \mu \mathrm{g} \mathrm{LH} / \mathrm{ml}$ did not significantly increase the percentage of oocytes reaching the blastocyst stage above that in follicles cultured without gonadotrophins or with lower levels of gonadotrophin.

The addition of gonadotrophins at the low and high levels did, however, significantly increase the percentage of fragmented oocytes above that seen in oocytes cultured in the absence of hormones $\left(29 \%\right.$ versus $\left.13 \% ; \chi_{1}^{2}=7.4 ; P<0.01\right)$.

Cultured with gonadotrophins and steroid. In large follicles (3-5 mm diam.), the addition of oestradiol-17 $\beta$ to medium containing low levels of gonadotrophins increased sevenfold the percentages of oocytes developing normally to morulae and blastocysts over that in medium supplemented with gonadotrophins alone $\left(46 \%\right.$ versus $\left.7 \% ; \chi_{1}^{2}=32.9 ; P<0.001\right)$. The presence of oestradiol-17 $\beta$ in the medium had the additional beneficial effect of reducing the percentages of single-cell and of fragmenting eggs $(P<0.001$ and $P<0.05$ respectively).

The addition of oestradiol- $17 \beta$ to medium containing the higher concentrations of gonadotrophins did not increase the percentage of oocytes developing into blastocysts above that in medium containing gonadotrophins alone. Despite the presence of oestradiol-17 $\beta$, only $16 \%$ of oocytes cultured in media containing high gonadotrophin levels developed to blastocysts as compared with $46 \%$ of oocytes cultured with the lower levels of gonadotrophin $\left(\chi_{1}^{2}=8.0 ; P<0.01\right)$. Furthermore, high gonadotrophin concentrations increased markedly the rate of fragmentation of oocytes after transfer (34\% versus $\left.13 \% ; \chi_{1}^{2}=6.4 ; P<0.05\right)$. Significantly fewer oocytes from small follicles $(2-3 \mathrm{~mm}$ diam.) cultured in medium containing oestradiol-17 $\beta$ and low gonadotrophin concentration developed into blastocysts than those from larger follicles cultured in the same medium $\left(26 \%\right.$ versus $46 \% ; \chi_{1}^{2}=3 \cdot 9$; $P<0.05)$.

The combined results of this experiment suggest that the size of the follicle, whether or not it is atretic, and the concentrations of FSH, LH and oestradiol-17 $\beta$ pertaining during the culture period all critically influence the developmental potential of oocytes matured in vitro. Irrespective of the culture conditions, however, $15-20 \%$ of oocytes in each group underwent early cleavage before failure occurred; the block to cleavage occurred before the 32-cell stage in about $95 \%$ of the retarded oocytes in each group.

\section{Experiment 5: developmental capacity of oocytes cultured in atretic follicles}

Ovaries were obtained from untreated ewes slaughtered between Days 4 and 14 of the cycle. Large follicles (3-5 $\mathrm{mm}$ diam.) were isolated by dissection and identified as atretic or non-atretic; the latter group consisted of follicles in the secondary and tertiary stages of atresia only (Hay, Cran 
\& Moor, 1976). After $24 \mathrm{~h}$ in Medium 199A supplemented with FSH ( $2 \mu \mathrm{g} / \mathrm{ml}), \mathrm{LH}(1 \mu \mathrm{g} / \mathrm{ml})$ and oestradiol-17 $\beta(1 \mu \mathrm{g} / \mathrm{ml})$, oocytes were transferred to recipient ewes and embryonic development assessed as described previously.

Table 5 shows that there was no significant difference between atretic and non-atretic follicles in the percentage of oocytes developing to blastocysts after transfer $(45 \%$ and $50 \%$ respectively). These results were, moreover, almost identical with those obtained when follicles from PMSG-treated ewes were used (Exp. 4, Table 4).

Table 5. Effect of follicular atresia on the developmental potential of sheep oocytes cultured* for $24 \mathrm{~h}$ within the follicle and then transferred to the oviducts of inseminated recipient ewes for 7 days

\begin{tabular}{|c|c|c|c|c|c|c|c|}
\hline \multirow{3}{*}{$\begin{array}{c}\text { State } \\
\text { of } \\
\text { follicle }\end{array}$} & \multirow{2}{*}{\multicolumn{2}{|c|}{ No. of oocytes }} & \multicolumn{5}{|c|}{ Embryonic development } \\
\hline & & & \multirow{2}{*}{$\begin{array}{l}\text { Single- } \\
\text { celled } \\
\text { eggs }\end{array}$} & \multirow{2}{*}{$\begin{array}{c}\text { Fragmented } \\
\text { eggs }\end{array}$} & \multirow{2}{*}{$\begin{array}{c}\text { Retarded } \\
\text { eggs } \\
(2-50 \text { cells })\end{array}$} & \multirow{2}{*}{$\begin{array}{c}\text { Morulae } \\
(50-100 \\
\text { cells })\end{array}$} & \multirow{2}{*}{$\begin{array}{l}\text { Blastocysts } \\
(>100 \text { cells })\end{array}$} \\
\hline & Transferred & Recovered & & & & & \\
\hline Non-atretic & 54 & 46 & 10 & 10 & 6 & 2 & 18 \\
\hline Atretic & 31 & 24 & 4 & 6 & 2 & 2 & 10 \\
\hline Total & 85 & 70 & 14 & 16 & 8 & 4 & 28 \\
\hline
\end{tabular}

* In Medium 199A supplemented with $2 \mu \mathrm{g}$ NIH-FSH-S8/ml, $1 \mu \mathrm{g}$ NIH-LH-S18/ml and $1 \mu \mathrm{g}$ oestradiol-17ß/ml.

\section{Experiment 6: viability of morulae and blastocysts matured in vitro}

To test further the viability of embryos developed from intrafollicular oocytes, 34 blastocysts and 4 morulae selected randomly from Exps 4 and 5, were transferred to the uteri of 22 non-pregnant ewes which had exhibited oestrus 7 days previously. As controls, 42 blastocysts obtained 7-9 days after oestrus from ewes injected previously with 1250 i.u. PMSG were transferred directly to the uteri of 21 synchronized recipient animals. At term 16 recipients $(73 \%)$ with oocytes matured in vitro gave birth to 24 normal lambs (63\% embryonic survival). In the control group 15 ewes lambed ( $71 \%$ ) and 22 lambs were born ( $52 \%$ embryonic survival).

\section{Discussion}

Nuclear activation of mammalian oocytes released from the follicle has been reported for many species including the sheep (Jagiello, Ducayen, Miller, Graffeo \& Fang, 1975). Our findings demonstrate that the presence of a second meiotic metaphase figure in cultured oocytes is not necessarily synony. mous with oocyte maturation. The only valid guide to complete oocyte maturation at present is the capacity of the oocyte to develop after fertilization to at least the blastocyst stage. It is important that the earlier cleavage stages are not used as a measure of normal maturation since many abnormalities induced during culture are not detectable until blastulation with the criteria used.

In the rabbit, abnormalities associated with the formation of the male pronucleus account, in large measure, for the failure of fertilization and subsequent development of oocytes cultured outside the follicle (Thibault \& Gérard, 1973). The present study was'not"designed to provide direct information on pronuclear formation and fertilization. However, abnormalities in protein synthesis in extrafollicular oocytes during maturation have recently been identified (Warnes, Moor \& Johnson, 1977). It is probable that the new proteins synthesized during the later stages of maturation relate directly to post-maturational events associated with fertilization and early cleavage. The absence of new protein synthesis in extrafollicular oocytes could thus account for their subsequent developmental incompetence.

In contrast to the consistent failure to induce maturation in oocytes freed from the follicle, we have found that $40-50 \%$ of sheep oocytes matured within intact follicles in vitro subsequently de- 
veloped normally to term. Similar results have been obtained by Thibault \& Gérard (1973) with preovulatory follicles from oestrous does. Our experiments with sheep demonstrate that the potential for complete maturation in vitro is not restricted to the preovulatory follicle but can be induced in oocytes from non-atretic and atretic follicles obtained at any stage of the cycle.

It has been shown that cellular structure (Fainstat, 1968) and steroidogenic output (Moor, 1973) in cultured follicles are best sustained by a gas phase rich in oxygen. However, in conditions of high oxygen tension, spontaneous and often abnormal nuclear changes occur in many of the intrafollicular oocytes (Hay \& Moor, 1973). The differing optimal gas requirements within the follicle can be satisfied by using a gas phase of $5 \% \mathrm{CO}_{2}$ in air under hyperbaric conditions (Baker \& Neal, 1972). Our experiments suggest that hyperbaric pressures of about $1.5 \times 10^{5} \mathrm{~Pa}$ are optimal for the culture of sheep follicles. Oestrogen production from follicles cultured for $24 \mathrm{~h} \mathrm{in} 5 \% \mathrm{CO}_{2}$ in air at this pressure is similar to that from follicles cultured in a gas phase of $45 \%$ oxygen (44.4 \pm 7.9 and $55 \cdot 8 \pm 8 \cdot 1$ $\mathrm{ng} / \mathrm{mg}$ tissue $/ 24 \mathrm{~h}: \mathrm{R}$. M. Moor, unpublished observations). At $1 \times 10^{6} \mathrm{~Pa}$ (the pressure found satisfactory by Thibault \& Gérard (1973) for rabbit follicles) cellular involution and reduced steroid production occur in sheep follicles.

Under hyperbaric conditions, follicle-enclosed sheep oocytes remain in the germinal vesicle stage with compact cumulus and corona until gonadotrophin is added. The addition of gonadotrophin activates the meiotic process in sheep oocytes and induces structural changes in the surrounding cumulus cells; similar hormonally induced changes occur in follicle-enclosed oocytes of the rat (Tsafriri, Lindner, Zor \& Lamprecht, 1972), mouse (Baker \& Neal, 1972), rabbit (Thibault \& Gérard, 1973), cow and pig (Foote \& Thibault, 1969). The extent to which gonadotrophins initiate nuclear change in vitro appears, from our studies, to be directly related to the size of the follicle and its state of atresia. Oocytes in small non-atretic follicles respond poorly to gonadotrophin probably because of the overriding inhibitory effect of the follicular fluid (Chang, 1955) and granulosa cells (Foote \& Thibault, 1969). The degree of inhibition imposed upon the oocyte is reduced or modified during the subsequent growth of the follicle. Changes in the pattern of gonadotrophin binding during follicular development may well contribute to this apparent reduction in the inhibitory properties of large follicles. Virtually all oocytes in large follicles undergo maturational changes in vitro in response to gonadotrophic stimuli. During atresia, granulosa cell involution may well be accompanied by a reduction in the inhibitory factors secreted by those cells. As a result, oocytes in large and small atretic follicles might then respond more readily to administered gonadotrophins. The present findings show that nuclear maturation in oocytes from atretic follicles of all sizes occurs much more frequently than in the smaller non-atretic classes of follicles.

It is noteworthy that the cumulus cells and oocytes in sheep follicles are not subject to the same extensive degenerative changes as those that occur in the membrana granulosa during secondary and tertiary atresia (Hay et al., 1976). Minor degenerative changes are detectable in the cumulus during secondary atresia but these changes do not become widespread until the tertiary stages of atresia are reached. The structural integrity of the ooplasm and the vesicular condition of the oocyte nuclei, however, are retained until the follicle is in an advanced state of degeneration. When atretic follicles are placed in tissue culture, cellular degeneration is arrested and after $24 \mathrm{~h}$ in vitro some early signs of granulosa cell regeneration may be detected. The results obtained by transplantation of oocytes from atretic follicles support the morphological findings by demonstrating that the developmental capacity of oocytes is retained even in the more advanced stages of atresia.

It has been reported that an irreversible blockage occurs at the first anaphase division in a large proportion of mouse oocytes cultured in unsatisfactory media (Edwards, 1965). In the present study anaphase I nuclei were found in $27 \%$ of sheep oocytes from large non-atretic follicles cultured for $24 \mathrm{~h}$; by contrast very few oocytes from small non-atretic or atretic follicles had nuclei arrested at the first anaphase division. It has not been possible to determine whether or not some of the oocytes in our study were permenantly arrested in the anaphase I configuration. That this might be the case is suggested by the close relationship, after culture in medium containing gonadotrophin and oestrogen, between the percentage of oocytes matured to the second meiotic metaphase and the percentage of normal embryos obtained from follicles of different sizes and states of atresia. Modification of the culture conditions may affect both these factors. 
While the involvement of gonadotrophins in oocyte maturation is widely acknowledged, evidence has been presented to suggest that steroids do not play an important part in that process (Foote \& Thibault, 1969). Moreover, meiotic change is not arrested in follicles cultured in the presence of cyanoketone or aminoglutethimide, two powerful inhibitors of steroid biosynthesis (Lindner et al., 1974). Our results support the view that gonadotrophins, even without steroid supplementation, readily induce nuclear activation in sheep oocytes. The presence of a second meiotic metaphase figure in the nucleus is, however, in no sense an adequate indication of normal maturation of the oocyte. It is our contention that full oocyte maturation, rather than restricted nuclear changes only, is regulated by gonadotrophins and by steroids. This accords well with the conclusion of Baker \& Neal (1972) that oestrogen and gonadotrophin act synergistically when added to explants of mouse ovaries. The involvement of oestrogens in the maturation of pig oocytes has recently been postulated by Hunter, Cook \& Baker (1976) from the observation that increasing concentrations of intrafollicular oestrogen correlated closely with normal maturation and fertilization of oocytes. There is, moreover, preliminary evidence to suggest that the acquisition of a 'Male Pronucleus Growth Factor' (Thibault \& Gérard, 1973 ) in human and rabbit oocytes may be facilitated by oestradiol-17 $\beta$ in conjunction with other steroids (Thibault et al., 1975). The possible involvement of steroids in the maturation of oocytes in mammals would have a counterpart in amphibians in which steroids, and particularly progesterone, play a key role in the induction of the maturation process (see Smith, 1975).

We are indebted to Professor T. R. R. Mann, Dr C. Polge, Dr R. F. Hunter and Dr Mary Hay for advice and criticism during the preparation of the manuscript. The gonadotrophins were generously donated by the Endocrine Study Section, National Pituitary Agency, National Institutes of Health, Bethesda, U.S.A.

\section{References}

Austin, C.R. (1961) The Mammalian Egg. Blackwell Scientific Publications, Oxford.

Baker, T.G. \& Neal, P. (1972) Gonadotrophin-induced maturation of mouse Graafian follicles in organ culture. In Oogenesis, Chap. 10, pp. 377-396. Eds J. D. Biggers \& A. W. Schuetz. University Park Press, Baltimore.

Chang, M.C. (1955) The maturation of rabbit oocytes in culture and their maturation, activation, fertilization and subsequent development in the Fallopian tubes. J. exp. Zool. 128, 379-405.

Cross, P.C. \& Brinster, R.L. (1970) In vitro development of mouse oocytes. Biol. Reprod. 3, 298-307.

Edwards, R.G. (1965) Maturation in vitro of mouse, sheep, cow, pig, rhesus monkey and human ovarian oocytes. Nature, Lond. 208, 349-351.

FAINSTAT, T. (1968) Organ culture of postnatal rat ovaries in chemically defined medium. Fert. Steril. 19, 313338.

Foote, W.D. \& Thibault, C. (1969) Recherches expérimentales sur la maturation in vitro des ovocytes de truie et de veau. Annls Biol. anim. Biochim. Biophys. 9, 329-349.

HaY, M.F. \& Moor, R.M. (1973) The Graafian follicle of the sheep: relationships between gonadotrophins, steroid production, morphology and oocyte maturation. Annls Biol. anim. Biochim. Biophys. 13, 241248.

Hay, M.F., Cran, D. \& MoOR, R.M. (1976) Structural changes occurring during atresia in sheep ovarian follicles. Cell Tiss. Res. 169, 515-529.
Hunter, R.H.F., CoOK, B. \& BaKer, T.G. (1976) Dissociation of response to injected gonadotrophin between the Graafian follicle and oocyte in pigs. Nature, Lond. 260, 156-158.

Jagiello, G., Ducayen, M., Miller, W., Graffeo, J. \& FANG, J.S. (1975) Stimulation and inhibition with LH and other hormones of female mammalian meiosis in vitro. J. Reprod. Fert. 43, 9-22.

Lindner, H.R., TSAFrifi, A., Lieberman, M.E., Zor, U., KoCH, Y., BAUMinger, S. \& BARNeA, A. (1974) Gonadotrophin action on cultured Graffian follicles: induction of maturation division of the mammalian oocyte and differentiation of the luteal cell. Recent Prog. Horm. Res. 30, 79-138.

McGaughey, R.W. \& Polge, C. (1971) Cytogenetic analysis of pig oocytes matured in vitro.J. exp. Zool. 176, 383-395.

MooR, R.M. (1973) Oestrogen production by individual follicles explanted from ovaries of sheep. $J$. Reprod. Fert. 32, 545-548.

Moor, R.M., HAY, M.F., McInTosh, J.E.A. \& CALDWELL, B.V. (1973) Effect of gonadotrophins on the production of steroids by sheep ovarian follicles cultured in vitro. J. Endocr. 58, 599-611.

MUKHERJEe, A.B. (1972) Normal progeny from fertilization in vitro of mouse oocytes matured in culture and spermatozoa capacitated in vitro. Nature, Lond. 237, 397-398.

Pincus, G. \& Enzmann, E.V. (1935) The comparative behaviour of mammalian eggs in vivo and in vitro. J. exp. Med. 62, 665-675. 
SMITH, L.D. (1975) Molecular events during oocyte maturation. In The Biochemistry of Animal Development, Vol. III, Chap. 1, pp. 1-46. Ed. R. Weber. Academic Press, London.

Thibault, C. \& Gérard, M. (1973) Cytoplasmic and nuclear maturation of rabbit oocytes in vitro. Annls Biol. anim. Biochim. Biophys. 13, Suppl., 145-156.

Thibault, C., Gérard, M. \& Menezo, Y. (1975) Acquisition par l'ovocyte de lapine et de veau du facteur de décondensation due noyau du spermatozolde fécondant (MPGF). Annls Biol. anim. Biochim. Biophys. 15, 705-715.
Trounson, A.O., Willadsen, S.M. \& Rowson, L.E.A. (1976) The influence of in-vitro culture and cooling on the survival and development of cow embryos. J. Reprod. Fert. 47, 367-370.

TSAFRIRI, A., LNNDNER, H.R., ZOR, U. \& LAMPRECHT, S.A. (1972) In-vitro induction of meiotic division in follicle-enclosed rat oocytes by LH, cyclic AMP and prostaglandin $\mathrm{E}_{2}$. J. Reprod. Fert. 31, 39-50.

Warnes, G.M., Moor, R.M. \& Johnson, M.H. (1977) Changes in protein synthesis during maturation of sheep oocytes in vivo and in vitro. J. Reprod. Fert. 49 (in press).

Received 11 August 1976 